\title{
Developing a Hybrid Learning Strategy for Students' Engagement in Object-Oriented Programming Course
}

\author{
Heni Jusuf ${ }^{1,2, *}$, Nurdin Ibrahim ${ }^{3}$, Atwi Suparman ${ }^{4}$ \\ ${ }^{1}$ Post Graduated Universitas Negeri Jakarta, Indonesia \\ ${ }^{2}$ Department of Engineering, Faculty of Engineering and Science, Universitas Nasional, Indonesia \\ ${ }^{3}$ Educational Technology, Univesitas Negeri Jakarta, Indonesia \\ ${ }^{4}$ Educational Technology, Faculty of Teacher Training and Education, Universitas Terbuka, Indonesia
}

Received July 9, 2019; Revised September 9, 2019; Accepted September 16, 2019

Copyright $\odot 2019$ by authors, all rights reserved. Authors agree that this article remains permanently open access under the terms of the Creative Commons Attribution License 4.0 International License

\begin{abstract}
This research is conducted on the application of Object-Oriented Programming, aiming to examine improvements in engagement, performance, and interaction of students in OOP class through the application of hybrid learning strategies, and then compare them with traditional class methods. This research study sought to improve students' engagement and their performance using the OOP class and implement the hybrid learning strategy and compare students' interaction at a class that using hybrid learning strategy with traditional one. The hybrid learning strategy is a teaching strategy to improve students' engagement and performance from traditional class to Virtual Learning Environment and exercise programming inside the class through activities of learning. Changes in students' attitudes and perceptions were evidence. To evaluate before and after the test, a teacher created several units of the tests, and interview randomly. Observation of research, experiences, thoughts, and insights into the virtual learning environment was carried out at each learning. Quantitative and qualitative results revealed that the students favorably responded to the hybrid learning strategy and they had increased in their engagement and communication when both compared to the traditional class. Results of the study was found that sig.t $=0.03<\alpha=$ 0.05 , it was concluded that $\mathrm{H} 02$ was rejected and resulted in the acceptance of Ha2: $\mu \mathrm{A}>\mu \mathrm{B}$; this means that the average learning outcomes of students who take hybrid learning were higher than students who take part in learning activities using traditional learning. The students acknowledge the quality improvement in learning and using hybrid learning strategy in the class. Regarding academic performance, there are significant changes shown between hybrid learning strategy class and the traditional learning class environment.
\end{abstract}

Keywords Hybrid Learning Strategy, Object Oriented
Programming, Active Engagement, Academic Performance, Virtual Learning Environment

\section{Introduction}

The development of computer and internet technology is currently very rapid; it can be seen from the emergence of various kinds of services, which are turning into online services. The emergence of the development of the internet makes all the information needed can be obtained easily and quickly. In fact, Information Technology is a part of modern society's life.

Programmer is someone who can solve problems using a programming language. They have many abilities consisting of various levels, they are good at writing code, understanding algorithms and often working alone (Permana, 2016). The need for programmers every year is increasing, along with technological advances, but this is not accompanied by graduates from the Informatics Department who intend to become programmers (Capgemini Digital Transformation Institute survey, 2017). The Informatics Study Program is a study program that attracts many students, but their enthusiasm decreases rapidly in the second year because they have difficulty in learning Programming; programming courses have a huge portion, so if they have problems in this course, students will fail.

Object-Oriented Programming (OOP) was chosen in this study because OOP is very suitable for making large applications. OOP allows us to update or maintain applications without the need to overhaul from zero, and OOP is ideal for making team applications.

The results of the study of 81 respondents of Informatics students in the OOP course are as shown in table 1 below: 
Table 1. Results of the questionnaire on current OOP learning based on Percentage

\begin{tabular}{|c|l|c|c|c|c|c|}
\hline No & \multicolumn{1}{|c|}{ Items } & Strongly agree & Agree & Neutral & Disagree & Strongly Disagree \\
\hline 1 & Like Programming courses & 26,8 & 31,7 & 32,9 & 4,9 & 3,7 \\
\hline 2 & Programming courses are too difficult & 9,8 & 19,5 & 45,1 & 18,3 & 7,3 \\
\hline 3 & Programming courses are not interesting & 31,7 & 7,3 & 30,5 & 28 & 2,4 \\
\hline 4 & Programming courses are boring & 30,5 & 13,4 & 30,5 & 24,4 & 1,2 \\
\hline 5 & Teaching Lecturers are not proactive & 13,4 & 17,1 & 35,4 & 30,5 & 3,7 \\
\hline 6 & The teaching method is not interesting & 28 & 11 & 36,6 & 6,1 & 18,3 \\
\hline 7 & $\begin{array}{l}\text { The lecturer does not evaluate the achievement of a } \\
\text { material at each meeting session }\end{array}$ & 32,9 & 13,4 & 7,3 & 22 & 24,4 \\
\hline
\end{tabular}

Modifications and variations in learning at the higher education level are developed by developing computer and internet technology-based learning models. In the world of higher education, the background of the learners is very heterogeneous, meaning that the learners do not only come from secondary school graduates but also those who have worked so that with a background of very varied learners, the learning needs and styles of learners also vary. (Hampus Gunnrup, 2017) taught the concepts of Object Oriented Programming to children using a design science approach and the development of artifacts. The results show that teaching Object-Oriented Programming to school students can be done. Hybrid Learning is now a trend (Bernard, Borokhovski, Schmid, Tamim, \& Abrami, 2014) which has been developed as a learning model in universities, and this model can be in the form of learning using the web, games, videos and more (McGloin, McGillicuddy, \& Christensen, 2017). This model makes students engaged with learning materials that depend on how they are designed and delivered (IUCEL, 2018). In general, hybrid learning is web-based learning with an open environment that can be accessed through the internet with the aim of facilitating learning and building learners' knowledge through meaningful interactions. Some studies show that the use of the right learning media can accelerate and enhance the interaction among teachers, learners, and instructors; so that the development of learning media becomes a necessity in learning. The choice of a hybrid learning model is to overcome the above problems because based on a survey of internet users. Indonesia occupies the fourth position concerning users who spend a lot of time on the internet.

\section{Literature Review}

Some studies show that the use of appropriate instructional media can accelerate and enhance the interaction among instructors, learners, and teaching materials. (Lucia M.M.Giraffa, 2013) stated that there had been a declining number of students majoring in Information Technology (IT) and Computer Science, due to the dropout rate from students who majored in computer science, because programming courses had a high failure rate and became barriers for students, for years they tried to improve teaching methods. (Biju, 2013) There are problems faced by lecturers to teach Programming to undergraduate students. The students found difficulties in understanding the Object-Oriented concepts. Students who received procedural programming courses found difficulties in proceeding to OOP courses. They need time to understand Object-Oriented concepts. Various teaching approaches have been proposed to teach OOP. (Xinogalos, 2009). (Alhazbi, 2010) Students feel that the programming concepts difficult to understand; the students feel they lack skills to develop the right program. This situation reduces their motivation and causes many students to move on careers that do not require programming skills. Since lecture methods seem to be ineffective in teaching programming, then the different teaching approaches and methods have been studied to improve programming learning for novice students such as using games(Seng \& Yatim, 2014), visualization, (van der Meij, van der Meij, Voerman, \& Duipmans, 2017) active learning (Kahn, Everington, Kelm, Reid, \& Watkins, 2016), and project-based styles (Tumewu, Wulan, \& Sanjaya, 2017). Students assess that the use of e-learning in programming courses, as a supplement or as a substitute of lectures in class is to motivate, be easy to use, useful, efficient, exciting, and is a must (Handriyani, 2015).

The definition of learning is based on Behaviorism and Cognitivism, namely: The first is a change in behavior; the other is a change in mental representations or associations (Abbie H. Brown, 2016). Robert M. Gagne (J.Luterbach, 2018). Learning is a form of change that is shown in behavior changes through the experience of instructors and learners, from before learning and after learning process.

Learning is a system consisting of various components that are interconnected with one another. The components include learning objectives, learning resources, methods, media, and evaluation. Learning is any systematic and deliberate effort to create a process of interaction between students and educators and learning resources in a learning environment (Suparman, 2014).

The definition of Hybrid Learning (AECT, 2013) is the same as Blended learning, Blended learning is an instructional design where classroom and online (mediated) learning is integrated into educationally meaningful ways. 
The term hybrid is often used interchangeably with blended though blended is the more commonly used of the two (Jared Stein, 2014). Course is called blended, if a portion of the content delivered online is thirty to seventy-nine percent; the course is web-facilitated if online portion is one to twenty-nine percent, and it is called as online if eighty percent of the content or more is through online (Khe Foon Hew, 2014).

According to the learning theory by (Bandura, 1977), that environment shapes behavior, and behavior shapes the environment; this is in line with the current student environment who are accustomed to using information and communication technology devices that have been connected to the internet so that learning materials to be developed are web-based. Teacher needs to implement instructional strategies that engage students in activities that build both cognitive and conactive skills (Michael Simonson, 2015).

Cone of experience (Davis, 2015) in Dale illustrates that the learning experience gained can go through the process of action or experience for yourself what is learned. Learning is divided into two types, namely active learning and passive learning. In passive learning, reading contributes to mastering material and memory by ten percent $(10 \%)$, listening to twenty percent $(20 \%)$, and seeing contribute thirty percent (30\%). However, active learning, where when someone says, teaches, demonstrates, or discusses, it can give seventy percent (70\%) understanding and memory of the material mastered, and if active in doing/applying knowledge, it contributes ninety percent $(90 \%)$ to understanding and our memory of something.

Assessment of basic competencies is carried out based on indicators of achievement of competencies that contain one or more domains (Cognitive, Affective, and Psychomotoric) related to the cognitive realm, namely the ability to think, which includes intellectual abilities, ranging from the ability to remember until to solve problems.

Mentimeter is a web-based application, where lecturers can start learning with class polls to measure moods, warm-up material, or ask essential questions to students. Use the Priority Action Matrix to determine which skills are taught first (engagement students in planning learning) and do a quick assessment using the quiz feature to check mastery of concepts anonymously. Lecturers can also use Word Cloud to brainstorm a topic or a solution to real-world problems. Group discussions using questions related to scientific themes or discoveries can be easily implemented with this application (Davinda L.Hill, 2017).

The definition of Educational Technology based on AECT in 2004/2008 is "a study and ethical practice to facilitate learning and improve performance by creating, using, and managing various sources and processes." Educational-Technology is a complex and integrated process that involves people, procedures, ideas, tools, and organizations to analyze problems, find ways to solve the problem, apply, evaluate, and manage the resolution of problems related to all aspects of human learning.

\section{Methodology}

The research carried out is $\mathrm{R} \& \mathrm{D}$ research because it fulfills the four main features introduced by Borg and Gall, namely conducting preliminary studies to find information about learning products to be developed, developing products based on research findings, conducting field trials of products developed, revise the product based on the results of the trial so that it becomes a useful product that answers the need. Borg and Gall (Januszewski, 2001) define $\mathrm{R} \& \mathrm{D}$ research as a series of processes that must be carried out in developing and validating educational products, and how to build research steps in the field of educational technology.

\subsection{Participants}

This study uses two (2) classes, namely the Hybrid class consisting of thirty-five (35) students and Traditional class consisting of thirty-five (35) students who took OOP courses in the 4th semester of the Informatics Engineering study program. (Siti Zuraidah Md Osman, 2014) This study aims to determine the lecturer and students' perceptions and their achievement between two learning methods, and a traditional class and a hybrid class.

\subsection{Sampling Procedure}

In this study, students who took a hybrid class and face-to-face (traditional) class were taken randomly 35 face-to-face and 35 hybrid class, from the number of students applying for hybrid classes and face-to-face classes.

\subsection{Research Design}

This research uses the Action Science Research Design (Kevin R. Clark, 2015), (Norton, 2009) to collect quantitative data and qualitative data to assess the impact of the learning process that uses Hybrid Learning class and those who use face-to-face class (traditional class). Quantitative data comes from pre-test and post-test. Qualitative data comes from interviews with students, observations, and discussion group sessions. According to (Creswell, 2012) the mix method approach is useful for getting a deeper understanding of research.

\subsection{Procedure}

Hybrid Teaching Model and face-to-face in OOP courses are implemented in one semester. To increase students' engagement in OOP learning, hybrid classes use 
also a combination of face-to-face, namely, in a computer laboratory, lecturers teach practicum to make applications with OOP, and through online at VLE in Moodle, students learn by reading learning content as pdf file, watching video, and working on the questions in the form of online program code to understand logic and to analyze problems with code combat, code.org and digihub aplication; when the material in one session has been studied, the student uses the Mentimeter or kahoot application as an assessment, so that the lecturer is easy to monitor the results of the learning that has been done using mentimeter application. The mentimeter application is used for pre-test and post-test, because the mentimeter application is very interesting, real-time and easily monitored by students and lecturers.

For face-to-face class, the learning process is done in class, lecturers teach theory, and in computer laboratories to make programs, after finishing studying the material in one session, students working on test questions using the Mentimeter application before and after a test, because the Mentimeter application is interesting, real-time and monitored easily by students and lecturers. The results of each assessment session that uses Mentimeters in hybrid classes and face-to-face classes were analyzed whether there was material at one session. One hundred percent $(100 \%)$ students understood, mix of students understood and zero percent $(0 \%)$ of students did not understand; this was very useful for making decisions whether the previous session needs to be repeated.

\subsection{Instrumentation}

The instrument in this study used the Student Perception of Instruction Questionnaire (SPIQ) to compare hybrid learning with face-to-face learning (Muniandy, 2017) . In his study, Muniandy used instruments to measure the effect of using technology in improving students' learning and engagement in the learning process.

\subsection{Field Test}

Field tests were conducted before the adoption of a hybrid learning model, to assess the feasibility of interview instruments and focus group discussion (FGD) questions. Evaluation of instruments is carried out by experts. Experts are asked to determine whether the questions asked are obvious, the language is appropriate, open and in accordance with the research objectives. The feedback needs to simplify words in a number of questions, so students understand what is meant in the question.

\section{Results and Findings}

Our approach uses mixed-learning activities with three main phases. Figure 1 consists of (i) Observation of the OOP software development process, (ii) Application of problem-solving tasks with guided instructions, and (iii) Tasks of Autonomous Problem-Solving.

The blended-learning activity involves activities that use online learning resources and students' interactions with VLE. Engaging the students and sustaining their interest during online learning, it proves to be one of the challenges faced by educators to teach the new generation of learners. A virtual learning environment is used in figure. 2 as a hybrid-learning platform.

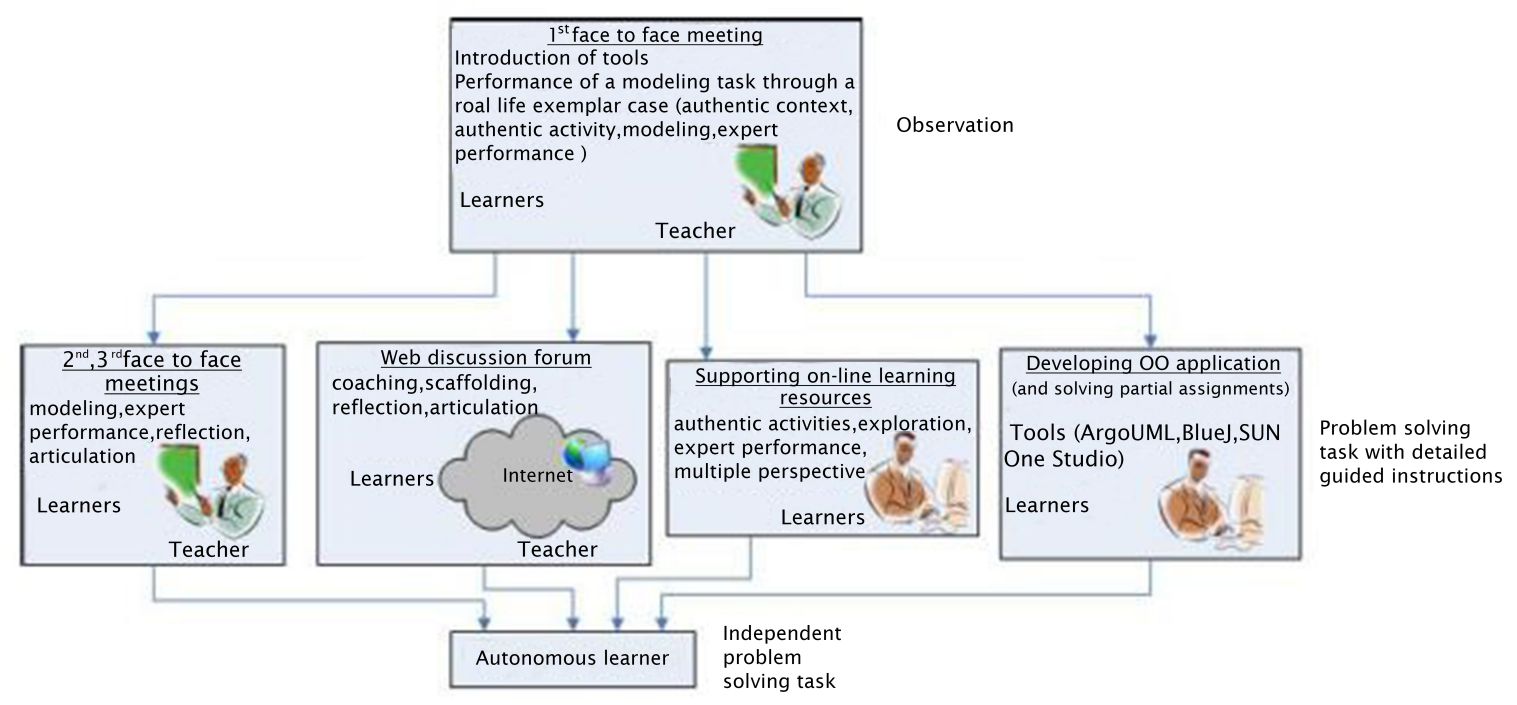

Figure 1. Phases and learning activities of the Proposed Learning for OOP (Yannis Psaromiligkos, 2007) 


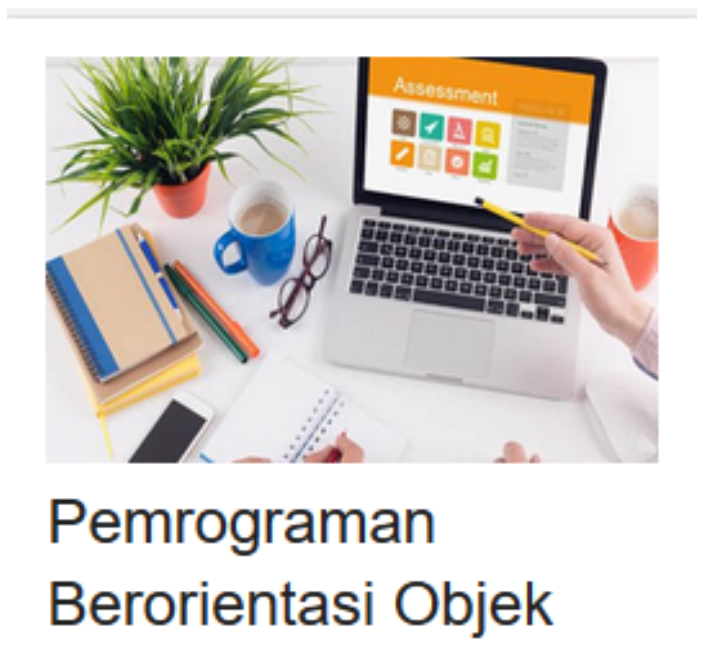

\author{
Matakuliah ini berhubungan dengan \\ sikap, pengetahuan, dan keterampilan \\ yang dibutuhkan dalam membuat \\ perangkat lunak aplikasi dalam Bahasa \\ Pemrograman Berorientasi Objek

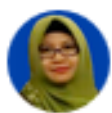 \\ Heni Jusuf \\ Universitas Nasional
}

Figure 2. Virtual Learning Environment (VLE)

\title{
4.1. Quantitative Results
}

The result of the quantitative analysis of this study is to test whether hybrid-based learning is better than traditional learning. To do the analysis, the researchers tested the hypothesis as follows:

Mathematical hypothesis

Hal: $\mu \mathrm{A} \neq \mu \mathrm{B}$

Ha2: $\mu \mathrm{A}>\mu \mathrm{B}$

A: Hybrid learning

B: Traditional learning

Researchers used 35 samples to test the hypothesis above that had been taken randomly and had followed the learning activities carried out in the experiment.

The results of statistical analysis using SPSS 22 with the results of the analysis as a Figure 3.

\section{Group Statistics}

\begin{tabular}{|cc|r|c|r|c|}
\hline & grub & N & Mean & Std. Deviation & \multicolumn{1}{c|}{$\begin{array}{c}\text { Std. Error } \\
\text { Mean }\end{array}$} \\
\hline nilai & 1.00 & 35 & 74.1943 & 13.00206 & 2.19775 \\
& 2.00 & 35 & 67.7971 & 11.20589 & 1.89414 \\
\hline
\end{tabular}

Figure 3. Statistical Analysis

Ha1: $\mu \mathrm{A} \neq \mu \mathrm{B}$ : The average value of Hybrid class tests with Traditional class is not the same. The hypothesis is valid based on analysis results at the table above where the mean value of the Hybrid class is higher than the mean value of the traditional class, which is $74.19 \neq 67.79$ 
Independent Samples Test

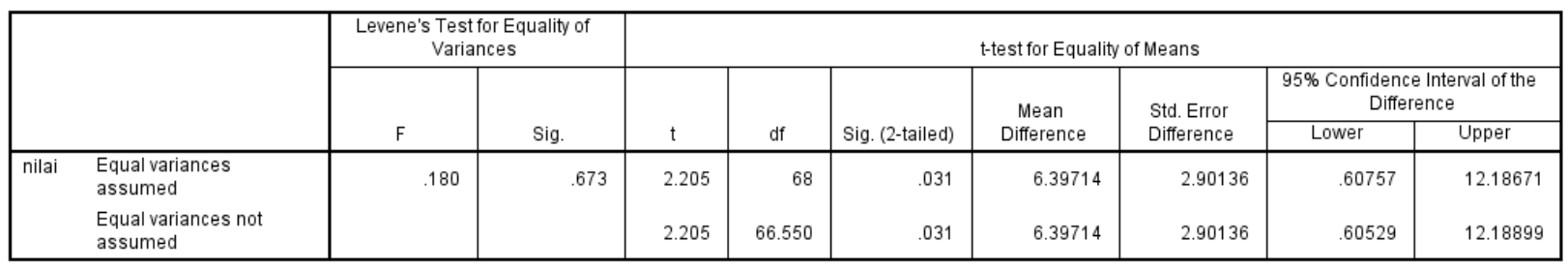

Figure 4. Table t

The hypothesis tested using Table $t$ in figure 4 is $\mathrm{Ha} 2$ : $\mu \mathrm{A}>\mu \mathrm{B}$ that is the average learning outcomes of students who take hybrid learning is higher than students who take traditional learning activities. From the Table above, it obtained a significant value of $t$ of 0.031 , using the criteria of a Significant Level of Error that is $\alpha=0.05$, then it can be concluded that the Significant Value $t$ is smaller than the limit value of error $\alpha=0.05$. The hypothesis acceptance criteria in this study are $\mathrm{H} 0$ accepted if sig.t $>\alpha=0.05$. From the results of the study, it was found that sig.t $=0.03$ $<\alpha=0.05$, it was concluded that $\mathrm{H} 02$ was rejected and resulted in acceptance Ha2: $\mu \mathrm{A}>\mu \mathrm{B}$ means that the average student learning outcomes following hybrid learning were higher than students who followed traditional learning activities.

\subsection{Quantitative Result}

The results on the feedback from the students of "f $(\mathrm{N}=35) "$ on the items that using the "5-point Likert scale" are shown in Table 2. Almost all of the students agreed that using VLE for hybrid learning provided several advantages, for example, instruction and navigation are easy to follow, the topic is easy to understand, and an online assignment was easy and useful for self-assessment and revision before the examination. These quantitative results are consistent with the comments of the students that VLE is a good learning system that helps us to refresh our memories at the module taught in class. The Mentimeter application on
VLE is an excellent tool for revising. It provides immediate feedback that we found very helpful, the interactive method that makes it easy for us to remember, understand and apply what we have learned, and overall, the Mentimeter application gives us an exciting way to make revisions. These advantages of the Mentimeter application are significant in education as part of the learning process of the students.

Results of the statements were indicative of a satisfactory student perception with hybrid learning in compared the traditional learning

Analysis has been carried out on 70 students who are currently taking OOP courses in table 3 , namely hybrid classes consisting of thirty-five (35) students, and traditional classes consisting of thirty-five (355) students. There are nine (9) questions that were asked in the survey to get students' opinions about the subjects they took; it can be seen from the results that around one hundred percent $(100 \%)$ of respondents strongly agree with Hybrid Learning lectures, particularly when involving the use of applications such as Moodle, code.org, YouTube, Mentimeter, and Kahoot as learning media.

The following keywords were found repeatedly in interviews and FGDs: Actively engaged in learning, better learning in class, the class is different from other class; interesting, the content is easier, direct learning, helpful, learn to be independent, learning individually. The following keywords were also found: teaching that innovative, interaction, more communications with peers and teachers, more participation, and technology. 
Tabel 2. Feedback from student by percentage on VLE

\begin{tabular}{|c|l|c|c|c|c|c|}
\hline No & \multicolumn{1}{|c|}{ Items } & $\begin{array}{c}\text { Strongly } \\
\text { agree }\end{array}$ & Agree & Neutral & Disagree & $\begin{array}{c}\text { Strongly } \\
\text { Disagree }\end{array}$ \\
\hline 1 & Log-in to VLE Moodle was easy & 82 & 16 & 2 & 0 & 0 \\
\hline 2 & Moodle features were flexible to use & 81 & 16 & 3 & 0 & 0 \\
\hline 3 & Instruction and navigation easy to follow & 62 & 33 & 5 & 0 & 0 \\
\hline 4 & Understanding of the topic & 55 & 40 & 4 & 1 & 0 \\
\hline 5 & Help in Self Study & 56 & 35 & 8 & 1 & 0 \\
\hline 6 & Online assignment was easy & & & & & \\
\hline 7 & Useful for revision before examination & 50 & 40 & 5 & 3 & 2 \\
\hline
\end{tabular}

Tabel 3. Student Survey by Percentase

\begin{tabular}{|c|l|c|c|}
\hline No & \multicolumn{1}{|c|}{ Items } & Hybrid Learning & Traditional Learning \\
\hline 1 & Overall, this was an excellent course & 65 & 35 \\
\hline 2 & I gained a good understanding of concepts & 87 & 13 \\
\hline 3 & The clarity of instruction was good & 89 & 11 \\
\hline 4 & I will use that l learn & 54 & 46 \\
\hline 5 & I deepened my interest in the subject matter of this course & 88 & 28 \\
\hline 6 & I was motivated to do well & 98 & 5 \\
\hline 7 & $\begin{array}{l}\text { I am confident in my ability to understand and apply concepts learned in } \\
\text { this course }\end{array}$ & 95 & 5 \\
\hline 8 & $\begin{array}{l}\text { I find online class delivery of accounting materials at least as effective as } \\
\text { traditional in-class delivery }\end{array}$ & 95 & 0 \\
\hline 9 & $\begin{array}{l}\text { I find online class delivery is more effective than traditional in-class } \\
\text { delivery }\end{array}$ & 100 & 2 \\
\hline
\end{tabular}

\subsection{Active Engagement and Learning}

Results for the students commented that hybrid learning encouraged active engagement more in OOP course. All of the participants in the FGD mentioned how they had experienced increases in the classroom to participate when it compared with the classroom before hybrid learning. Notably, the student had acknowledged their passive interactions during lectures and limited communication between their teacher and other peers before hybrid learning.

\subsection{Class Time and Structure}

When students compare traditional classes with hybrid classes, they feel hybrid classes are more interesting, because students can learn the learning material first, including watching videos, doing quizzes, while in traditional classes students just listen lecturers' lecture in class, which makes students feel bored. Some students commented they pretended to pay attention when the lecturer was teaching, even though at that time they were thinking about something else. The FGD session revealed that students get advantages with hybrid learning because they can repeatedly learn in VLE when they do not understand a material; this indeed cannot be obtained from traditional class students. Figure 5 is a VLE instructional design for hybrid classes. 
Master Schedule

\begin{tabular}{|c|c|c|c|c|c|c|c|c|}
\hline \multirow[b]{2}{*}{ Date } & \multirow[b]{2}{*}{ Topic } & \multirow[b]{2}{*}{ Subtopic } & \multicolumn{6}{|c|}{ Learning Activities With Due Dates } \\
\hline & & & $\begin{array}{l}\text { Reading } \\
\text { Assigment/ } \\
\text { Video } \\
\text { Presentation }\end{array}$ & Homework & $\begin{array}{l}\text { Self } \\
\text { Evaluation } \\
\text { Quiz }\end{array}$ & $\begin{array}{l}\text { Synchonous } \\
\text { Session }\end{array}$ & $\begin{array}{l}\text { Lab } \\
\text { Session }\end{array}$ & Exam \\
\hline $\begin{array}{l}\text { Week } \\
\# 1\end{array}$ & $\# 1$ & 1\# & $\begin{array}{l}\text { Vol1 \#P } \\
\text { Video\# }\end{array}$ & $\begin{array}{l}\text { HW \#1 } \\
\text { Book Vol 1 } \\
\text { \#p }\end{array}$ & Quiz \#1 & $\begin{array}{l}\text { In / off Class } \\
\text { Session } \\
\text { Disscus } \\
\text { about\# }\end{array}$ & - & - \\
\hline & & 2\# & & & & & & \\
\hline & & 3\# & & & & & & \\
\hline $\begin{array}{l}\text { Week } \\
\# 2\end{array}$ & $\# 1$ & 1\# & $\begin{array}{l}\text { Vol1 \#P } \\
\text { Video\# }\end{array}$ & $\begin{array}{l}\text { HW \#1 } \\
\text { Book Vol1 } \\
\# p\end{array}$ & Quiz \#2 & $\begin{array}{l}\text { In / off Class } \\
\text { Session } \\
\text { Disscus } \\
\text { about\# }\end{array}$ & - & - \\
\hline
\end{tabular}

Figure 5. VLE Instructional Design

\subsection{Quality of Teaching}

The results of interviews with students have revealed improved quality of teaching in Hybrid Learning. In particular, students compare hybrid classes with traditional classes. Some students do not feel direct instruction during online classes. On the contrary, students think that the hybrid teaching model is more effective and can be applied because of the variety of teaching methods incorporated in it, such as lesson content that is fully available, both text and video, direct assessment, independent assignment, group assignments, and collaborative based learning. Students thought previously that effective teaching was listening to lectures and taking notes; however, after experiencing hybrid learning, they gained a new understanding concerning effective teaching. At the end of learning, the students preferred the class in which various learning methods were used. Students feel the use of technology for facilitating learning can improve the quality of teaching. Students were interviewed and told about how the use of technology can increase their level of engagement. There are students who claim that using technology can lead to increased motivation to learn; others stated that his experience in online classes was exciting and fun. The students love to see online the learning media made by lecturers; at an unspecified time, they feel that they have access to learning material for twenty-four hours a day, which is quite profitable.

\subsection{Collaboration}

Students interviewed gave comments on improving the collaboration use model, and how it functions in increasing their participation and involvement in the class. A student commented on how supports and collaborations with other friends in class helped him to build confidence and increase his understanding of OOP content. He also mentioned the importance of working collaboratively to complete tasks related to direct learning activities and project-based assignments. Furthermore, as a result of the FGD, students get working-group assignments that are more effective than listening to the lectures, and note on face-to-face learning according to the lecture schedule; they agree on collaborative tasks that require them to take the active role in the learning process. Hybrid Teaching Model gives students the opportunity to work collaboratively and cooperatively to increase their involvement and performance.

\subsection{Communication}

The importance of communication among students and lecturers. The results of FGD show that students feel they can communicate more when online. Compared to traditional classes, students agree that there is more interaction between their classmates and lecturers when online. Students can discuss problems, share solutions, and express their thoughts. Students interviewed said that they had many opportunities to talk to lecturers every time an online class took place. Students see that improving communication is an essential contribution to their positive experience with a hybrid class.

\subsection{Discussion}

The results and findings of this research show that students engaged more in hybrid classes compared to traditional classes. The average value of Hybrid class tests 
with Traditional class is not the same. The hypothesis is valid based on the results of the analysis in the Group Statistics table above, where the mean value of the Hybrid class is higher than the mean value of the Traditional class, etc.

Students openly acknowledge passive interactions during college and the limited communication among lecturers and the other peers before hybrid class is conducted. Thus, the hybrid class has positive impacts on students' engagement. The lecturers made unit test results indicating that there are different performance capabilities between traditional and hybrid classes. Students work collaboratively with the various groups when learn each other by discussing the problems, explaining the procedures, and confirming of answers - lecturers functions as a facilitator, and directing when it needed.

\section{Conclusions}

The results and findings show that students have more engagement in hybrid learning compared to traditional learning. Students in hybrid learning class experience quality teaching that is student-centered and student-focused. Hybrid learning class makes it possible to increase the use of time with varied teaching strategies, including direct activities and the structure of the collaboration learning. While research on the effectiveness of the hybrid learning is limited, this research study provides additional and valuable information about the impact of the learning model on students' engagement and performance. Although the hybrid learning is relatively new technology for learning, it certainly has the potential to be considered useful in terms of increasing students' engagement and performance in the classroom. From the results of the study, it was found that sig.t $=0.03<\alpha=0.05$, and it was concluded that $\mathrm{H} 02$ was rejected and resulted in acceptance $\mathrm{Ha} 2: \mu \mathrm{A}>\mu \mathrm{B}$ means that the average student learning outcomes following hybrid learning were higher than students who followed learning activities with conventional methods. The student also recognized improvements in the quality of instruction and use of class with the hybrid learning strategy. In terms of academic performance, there was a significant change between the hybrid learning strategy and those who were taught in a traditional classroom environment.

\section{Acknowledgements}

This research work is supported by the Program Bantuan Seminar Luar Negeri Ditjen Penguatan Riset dan Pengembangan, Kemenristekdikti dan Univesitas Nasional.

\section{REFERENCES}

[1] Aktas, N., Croci, E., \& Petmezas, D. (2015). Is working capital management value-enhancing? Evidence from firm performance and investments. Journal of Corporate Finance, 30, 98-113.

[2] Deloof, M. (2003). Does working capital management affect profitability of Belgian firms?. Journal of business finance \& Accounting, 30(3-4), 573-588.

[3] Abbie H. Brown, T. D. G. (2016). The Essential of Intructional Desain (third ed.). New York Roudledge.

[4] AECT. (2013). Encyclopedia of Terminology for Educational Communications and Technology (R. C. Richey Ed.). USA: Springer.

[5] Alhazbi, S. (2010). Supportive Online Learning Environment to Improve students' Satisfaction in object-Oriented Programming Courses. Paper presented at the 2nd International Congress on Engineering Education, Kuala Lumpur, Malaysia.

[6] Bandura, A. (1977). Sosial Learning Theory (A. Bandura Ed.). New Jersey: Prentice Hall.

[7] Bernard, R. M., Borokhovski, E., Schmid, R. F., Tamim, R. M., \& Abrami, P. C. (2014). A meta-analysis of blended learning and technology use in higher education: from the general to the applied. Journal of Computing in Higher Education, 26(1), 87-122. doi:10.1007/s12528-013-9077-3

[8] Biju, S. M. (2013). Difficulties in understanding object oriented programming concepts. University of wollongong research online, 319-326.

[9] Capgemini Digital Transformation Institute survey. (2017). The Digital Talent GapAre Companies [Press release]. Retrieved from https://www.capgemini.com/wp-content/uploads/2017/10/i nfographic.pdf

[10] Creswell, J. W. (2012). Educational Research planning, Conducting, and Evaluating Quantitative and Qualitative Research. Nebraska: Pearson.

[11] Davinda L.Hill, K. F. (2017). Using Mentimeter to promote student engagement and inclusion. Paper presented at the Pedagogy in Practice seminar, Carlisle, UK. http://insight.cumbria.ac.uk/id/eprint/3473/

[12] Davis, B. S., Michele. (2015). Applying Dale's Cone of Experience to increase learning and retention: A study of student learning in a foundational leadership course. QScience Proceedings, 2015(4), 7. doi:10.5339/qproc.2015.elc2014.6

[13] Hampus Gunnrup, P. B. (2017). Children Learning Object Oriented Programming A Design Science Study (master), UNIVERSITY OF GOTHENBURG, Gothenburg, Sweden.

[14] Handriyani, Y. (2015). Persepsi Mahasiswa Terhadap Penggunaan e-learning Dalam Pembelajaran Bahasa Pemrograman di Fakultas Teknik UNP. Jurnal Teknologi Informasi Pendidikan, 8(1 Maret 2015), 10.

[15] IUCEL. (2018, 12th - 13th September 2018). Humanising Technologies. Paper presented at the International University Carnival on E-Learning, Kuala 
Lumpur,Malaysia.

[16] J.Luterbach, K. (2018). Designing and Developing Robust Instructional Apps (T. a. Francis Ed.). New York: Routledge.

[17] Januszewski, A. (2001). Educational Technology The Development of a Concept Colorado: Libraries Unlimited, Inc.

[18] Jared Stein, C. R. G. (2014). Essentials for Blended Learning A Standards Base Guide. New York: Routledge.

[19] Kahn, P., Everington, L., Kelm, K., Reid, I., \& Watkins, F. (2016). Understanding student engagement in online learning environments: the role of reflexivity. Educational Technology Research and Development, 65(1), 203-218. doi:10.1007/s11423-016-9484-z

[20] Kevin R. Clark, M. S. U., Wichita Falls. (2015). The Effects of the Flipped Model of Instruction on Student Engagement and Performance in the Secondary Mathematics Classroom. Journal of Educators Online. doi: DOI: 10.9743/JEO.2015.1.5

[21] Khe Foon Hew, W. S. C. (2014). Using Blended Learning Evidence Based Practice. London: Springer.

[22] Lucia M.M.Giraffa, M. C. M., Lorna Uden. (2013). Teaching Object-Oriented Programming in First-Year Undergraduate Courses Supported By Virtual Classrooms. Paper presented at the The 2nd International Workshop on Learning Technology for Education in Cloud Conference Paper retrieved from

[23] McGloin, R., McGillicuddy, K. T., \& Christensen, J. L. (2017). The impact of goal achievement orientation on student technology usage in the classroom. Journal of Computing in Higher Education, 29(2), 240-266. doi:10.1007/s12528-017-9134-4

[24] Michael Simonson, S. S., Susan Zvacek. (2015). Teaching and Learning at a Distance (Sixth Edition ed.). Charlotte, North Carolina: Information Age Publishing, Inc.

[25] Muniandy, V. A. P. (2017). Teacher's and Students' Perceptions Between Flipped Classroom and Traditional Classroom At Primary Tamil School. Paper presented at the Social Sciences Postgraduate International Seminar (SSPIS), Pulau Pinang, Malaysia.

[26] Norton, L. S. (2009). Action Research in Teaching and Learning. USA: Routledge.

[27] Permana, Y. (2016). Perbadaan Programmer dan Developer. Retrieved from https://www.codepolitan.com/perbedaan-programmer-dandeveloper

[28] Seng, W. Y., \& Yatim, M. H. M. (2014). Computer Game as Learning and Teaching Tool for Object Oriented Programming in Higher Education Institution. Procedia Social and Behavioral Sciences, 123, 215-224. doi:10.1016/j.sbspro.2014.01.1417

[29] Siti Zuraidah Md Osman, R. Z., Nur Eliza Mokhtar. (2014). Flipped Classroom and Traditional Classroom: Lecturer and Student Perceptions between Two Learning Cultures, a Case Study at Malaysian Polytechnic. International Education Research, 2(4), 9. doi:10.12735/ier.v2i4p16
[30] Suparman, M. A. ( 2014). Desain Instruksional Modern, Penerbit Erlangga, Jakarta. Jakarta: Erlangga.

[31] Tumewu, W. A., Wulan, A. R., \& Sanjaya, Y. (2017). Comparison between project-based learning and discovery learning toward students' metacognitive strategies on global warming concept. 1848, 060013. doi:10.1063/1.4983981

[32] van der Meij, H., van der Meij, J., Voerman, T., \& Duipmans, E. (2017). Supporting motivation, task performance and retention in video tutorials for software training. Educational Technology Research and Development, 66(3), 597-614. doi:10.1007/s11423-017-9560-z

[33] Xinogalos, S. (2009). A proposal for teaching Object-Oriented Programming to undergraduate students. International Journal of Teaching and Case Studies, 2(1), 41. doi:10.1504/ijtcs.2009.026298

[34] Yannis Psaromiligkos, S. R. (2007). Developing a blended learning strategy for teaching Object-Oriented Programming using the 'Model First' approach. Paper presented at the Proceedings of the Informatics Education Europe II Conference IEEII 2007. 